\title{
The use of geotechnologies in the landscape fragility analysis of medium lower Araguari river basin, Brazil
}

\author{
Thallita Isabela Silva Martins ${ }^{1}$ thallitaisabela@yahoo.com.br, Sílvio Carlos Rodrigues
}

\begin{abstract}
This paper presents the mapping of environmental fragility of Medium Lower Araguari River Basin, Minas Gerais State - Brazil. This was possible from the analysis of the various environment variables that complete the basin system, such as landforms, rocks, soils, land use and vegetable coverage. It was used as methodological basis the General Systems Theory, the Landscape Ecology and Environmental Geomorphology, together with the application of geospatial technologies and GIS. From the systemic and holistic analysis of the landscape, it was possible to produce various cartographic maps to represent the environmental aspects of the study area, enabling the correlation and the generation of the potential and emerging fragility maps.The main objective of this work is to test a methodology for assessing the natural fragility of erosion occurrence by correlating variables in a GIS environment. In this sense, the method of Weighted Overlay was used in an GIS environment for mapping parameters. The results generate 2 types of approach, one dealing with the potential of the basin natural weakness in which we obtained a distribution of $39.30 \%$ of the total area of the basin in the Lower class of fragility, and $29.20 \%$ Medium Class of Fragility and $26.37 \%$ for the High Class of Fragility. A second analysis is performed by inserting human activities that affect and improve the development of erosion processes, and showed that predominate in the watershed classes of Medium Fragility with $47.35 \%$ of the total area and $39.28 \%$ of the total area with Low Fragility.
\end{abstract}

Keywords: Geoprocessing, GIS, Weighted overlay, Environmental Planning, Araguari River, landscape analysis.

\section{El uso de geotecnologías en el análisis de la fragilidad del paisaje en la cuenca media-baja de río Araguari, Brasil}

\begin{abstract}
RESUMEN
Se presenta la cartografía de la fragilidad ambiental de la cuenca media-baja del río Araguari, Estado de Minas Gerais - Brasil, a través del análisis de las variables de la cuenca hidrográfica, tales como formas del terreno, rocas, suelos, uso del suelo y vegetación. Las bases metodológicas de la investigación se sustentaron en la Teoría General de Sistemas, la Ecología de Paisaje y la Geomorfología Ambiental, junto con la aplicación de tecnologías geoespaciales y SIG. A partir del análisis sistémico y holístico del paisaje, fue posible elaborar mapas que representan los aspectos ambientales del área estudiada, posibilitando con ello la correlación y la generación de los mapas de fragilidad del paisaje. El objetivo de esta investigación es probar una metodología para la evaluación de la fragilidad natural a los procesos de erosión, mediante la correlación de variables en un ambiente SIG. Se utilizó el método de Superposición Ponderada para obtener los parámetros de asignación. Los resultados aportaron dos tipos de información, la debilidad natural potencial de la cuenca, con una distribución de 39,30\% de la superficie total de la cuenca con Baja Fragilidad, 29,20\% con Media Fragilidad y 26,37\% con Alta Fragilidad. Un segundo análisis, agregando las actividades humanas como agentes que afectan y favorecen el desarrollo de los procesos de erosión, demostró existe un $47,35 \%$ de la superficie total con Media Fragilidad y 39,28\% de la superficie total con Baja fragilidad de la cuenca hidrográfica.
\end{abstract}

Palabras clave: Geoprocesamiento, SIG, superposición ponderada, planificación ambiental, río Araguari, análisis del paisaje.

Recibido el 20 de abril de 2012, aceptado el 12 de noviembre de 2012.

1 Federal University of Uberlândia, Institute of Geography, Av. João Naves de Ávila, 2121. Bloco 1H, Sala 1H16, Campus Santa Mônica CEP: 38.408-100. Uberlândia - MG. 


\section{INTRODUCTION}

The geotechnologies have currently been a powerful support for works in several areas, as geographical analysis, for the scientific knowledge advance as well as for decision makers of planning sectors. The demand for geoinformation containing spatial reference and associated mainly to the study of natural resources, has increased more and more due to the enlargement of necessities for spatialized knowledge.

Geotechnologies, also known as geoprocessing, comprises a group of technologies which compose several phases, which are: collecting, processing, treating and analysis of information which present geographic reference. They are composed by the association of hardware and software, which are important tools for the debate and decision making. In the group of geotechnologies one can point tools as the geographic information system, digital cartography, remote sensing and the global positioning system (ROSA 2007).

Having this been exposed, and also having as a target the evolution of tools for cartography, it becomes a great potential for environmental studies. As a product of analysis in remote sensing and geoprocessing, the digital cartography has constituted as great tool for both synthesis and analysis, from the application of several techniques, since the pre-processing of images of satellite or radar, to its classification and mapping, comprehending several scales of treatment.

The concept of Potential Fragility is associated with the natural characteristics of a particular region or area. In this study, it derives from the methodology proposed by ROSS (1994) and adopted by RODRIGUES (1998), who indicates that an environment without human intervention is considered in dynamic equilibrium, and therefore the forces of nature are those that determine the operation of natural processes. Thus, the dynamics of the environment has fragilities, i.e. natural attributes which favor the occurrence of changes, are determined by natural attributes. In the methodology proposed by ROSS (1994) these regions can be classified according to a greater or lesser possibility of natural degradation processes, i.e. differentiated possibilities of landscape changes. The Emerging Fragility concept according to this line of analysis occurs when the equilibrium of environment changes due to human actions, which change the dynamic environment, by changing one or more elements that constitute the landscape. The classification of Emerging Fragility is made from the recognition that the changes that occurred, unbalance in greater or lesser extent the equilibrium of the landscape and can be classified using thematic mapping.

Thus, this author has proposed a methodology which uses the integrated study of several elements that constitute Earth Stratum, such as climate, rocks, soils, landforms and vegetal coverage, which are directly or indirectly influenced by human acts, by the use of ground and other resources of nature.

The main objective of this paper is to present a test of the methodology proposed by ROSS (1992) applied to a watershed in the region of the Cerrado Biome. In this sense, as the proposed appraisal is based on thematic cartography, it presents itself as a result of the development of two maps. The first map represents the potential environmental fragility of the study area. The second map shows the emerging fragility. To achieve these objectives, we used GIS techniques, which provide the use of a comprehensive geographic database, which enabled the creation of thematic mapping and elaboration of the proposed maps.

The watershed has an area of around 1,180 $\mathrm{km}^{2}$, it is located in the northern portion of Triângulo Mineiro, in the Minas Gerais state (Brazil), belonging to the hydrographic 
basin of Araguari River. This way, the area under study corresponds to the medium-low course of Araguari River, which is located in the following coordinates: $18^{\circ} 32^{\prime} 00^{\prime \prime} \mathrm{S}$ in North latitude, $47^{\circ} 55^{\prime} 00^{\prime \prime} \mathrm{W}$ in east longitude, $18^{\circ} 59^{\prime} 00^{\prime} \mathrm{S}$ in south latitude and $48^{\circ} 30^{\prime} 00^{\prime}$ 'W in west longitude (Fig. 1).

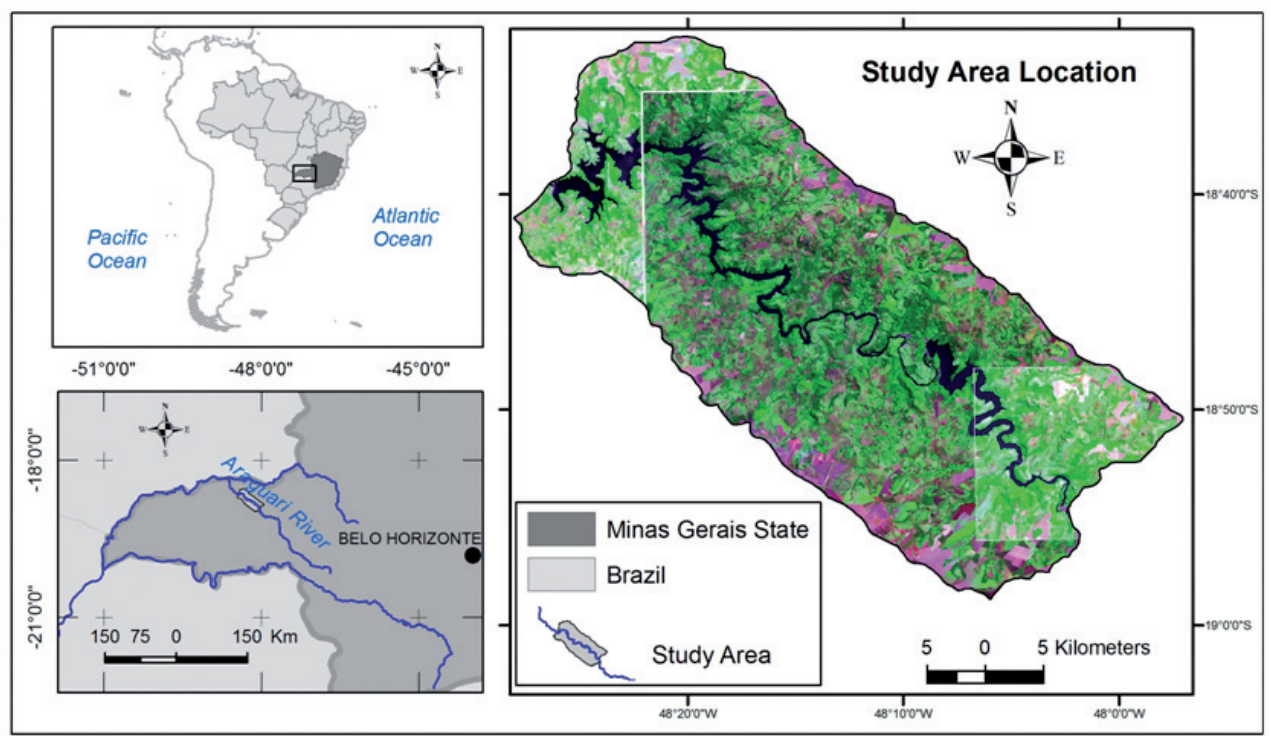

Fig. 1. Map with the location of Araguari River Medium-Lower Basin.

Fig. 1. Mapa de localización de la Cuenca media-baja del río Araguari

\section{MATERIALS AND METHODS}

The materials used for the empiric analysis of landscape fragility of the Medium Lower Araguari River Basin were:

- Cartographic Basis: maps of Geological units, Geomorphological units, Soils and Land Use and Vegetation Cover, in the scale of 1:100.000;

- $\quad$ Pack ArcGIS 9.3.1;

- Software ENVI (used specifically for the creation of the Map of Land use and Vegetation Cover)

The evaluation of Medium Lower Araguari River Basin environmental fragility was held from the preconceptions of ROSS (1994), PEDROSA et al. (2012). This latter has contributed for prudent analysis of geospatial attributes through ArcGIS, turned firstly to the evaluation of susceptibility of environment to natural risks. Several other authors used the prudent overlapping tool for the evaluation of susceptibility of environment facing various existing troubles. However, one has chosen to follow the one presented by PEDROSA et al. (2012), in the sense that this author focuses mainly the geomorphological analysis as an important means of defining environmental susceptibility. His methodology was adapted for this work, taking into consideration the studies of environmental fragility by ROSS (1994).

The methodology used here is based in the collecting information about Potential Fragility from the landforms analysis, which may express its different segments 
due to morphological characteristics, lithological threshold and the soils (ROSS 1994). Following this, one has proceeded to cross such information with the variables of Land Use and Vegetation Coverage, to get to the Emerging Fragility Map.

For such, it was used the proceeding of hierarchic attribution of values, for the association of environmental variables such as landforms, rocks, soils, land use and vegetable coverage. Each one of these variables was classified according to the higher or lower fragility facing erosive processes and instability of slopes, so that they received a non-parametric and qualitative classification, varying between Very low, Low, Medium, Strong and Very Strong classes.

With this, from what is proposed by PEDROSA et al. (2012), it was possible to build the environmental fragility model with the use of "Spatial Analyst" tools by means of prudent overlay (Weighted Overlay) of attributes, that is, giving them, apart from the fragility codes, the percentage values of influence they have over the environmental processes under analysis.

The procedure of Weighted Overlay consists of simple algebra application, through the cross of files in the Raster format. The logic is as follows: one supposes two raster data feeding, each one receives one classification of its cells within a scale ranging from 1 to 3. Each raster must receive an influence percentage, which varies from 0 to 1 . Thus, each cell is multiplied by the attributed percentage value, with the results added and transferred to the creation of a new raster. For instance, when one crosses a cell with value 2 , whose raster has received the influence of 0.75 ; and one cell with value of 3 and influence of 0.25 , one has $[(2 * 0.75)=1.5]$ and $[(3 * 0.25)=0.75]$. The addition of 1.5 and 0.75 is 2.25 ; however, the Weighted Overlay (ArcGIS) tool recognizes full results, so it rounds the final score to 2 (ESRI, 2008; Fig. 2). From what has been exposed, one can summarize the operational procedures according to the flow chart presented in figure 3 .

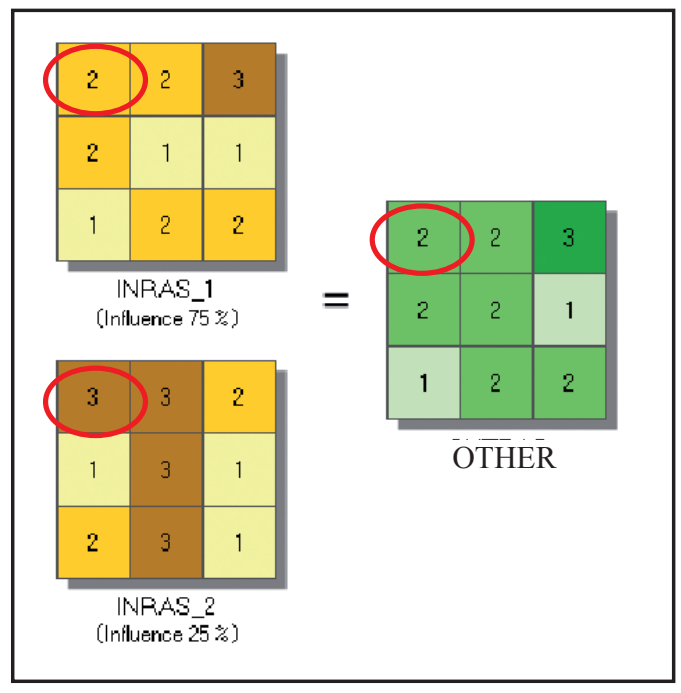

Fig.2. Scheme of Raster cell crossing.

Fig. 2. Esquema de cruce de Celdas Raster. 


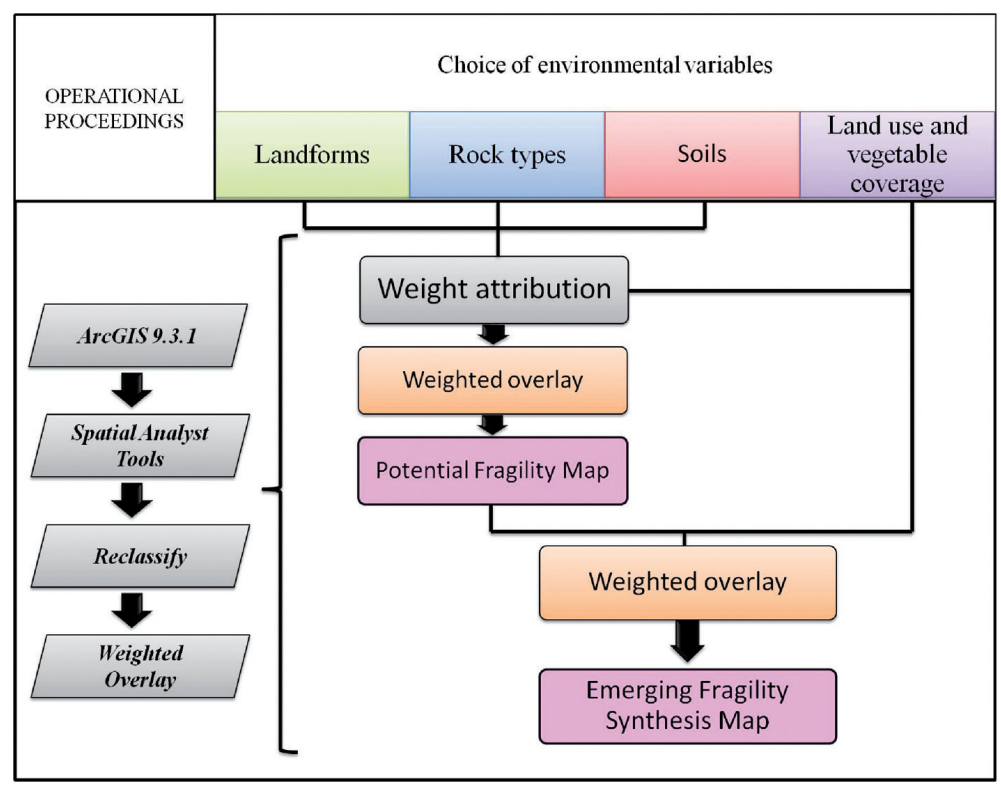

Fig. 3. Flow chart of operational procedures (SILVA 2010)

Fig. 3. Diagrama de flujo de procedimientos operacionales (SILVA 2010).

The classification of landscape attributes were used for the definition of Potential Fragility of the area under study. In addition, some considerations for each map created are made.

The geomorphological chart is one of the intermediate products for the elaboration of the fragility chart. This way, for the studies of areas represented in medium and small scales (in this case 1:100.000), one take as morphometric reference the Dissection Index Matrix of ROSS (1992) (Table 1), from which one has schematically established the level of influence in the fragility to the erosive processes.

Table 1: Matrix Of LANDForms dissection. Source: ROSS (1992) in SILVA(2010).

Tabla 1: Matriz de disección del paisaje. Fuente: ROSS (1992) en SILVA(2010)

\begin{tabular}{|c|c|c|c|c|c|}
\hline \multirow{2}{*}{$\begin{array}{l}\text { Depth of the valley } \\
\quad \text { (classes) }\end{array}$} & \multicolumn{5}{|c|}{ Interfluve average distance (classes) } \\
\hline & $\begin{array}{c}\text { Very large } \\
\quad(1) \\
>3.750 \mathrm{~m}\end{array}$ & $\begin{array}{c}\text { Large } \\
\text { (2) } \\
1.750 \text { to } 3.750 \mathrm{~m}\end{array}$ & $\begin{array}{c}\text { Medium } \\
\text { (3) } \\
750 \text { to } 1.750 \mathrm{~m}\end{array}$ & $\begin{array}{c}\text { Short } \\
\text { (4) } \\
250 \text { to } 750 \mathrm{~m}\end{array}$ & $\begin{array}{l}\text { Very Short } \\
\quad(5) \\
<250 \mathrm{~m}\end{array}$ \\
\hline Very weak $(1)<20 \mathrm{~m}$ & 11 & 12 & 13 & 14 & 15 \\
\hline weak (2) 20 to $40 \mathrm{~m}$ & 21 & 22 & 23 & 24 & 25 \\
\hline Medium (3) 40 to $80 \mathrm{~m}$ & 31 & 32 & 33 & 34 & 35 \\
\hline strong (4) 80 to $160 \mathrm{~m}$ & 41 & 42 & 43 & 44 & 45 \\
\hline Very strong $(5)>160 \mathrm{~m}$ & 51 & 52 & 53 & 54 & 55 \\
\hline
\end{tabular}


Morphometric index points to the lower values, the landforms with more moderate dissection, such as the 11, for instance; whereas the higher values point to more dissected landforms, such as 55 (ROSS 1992). In surfaces of tops absolutely plan (Dp), such as what occurs in the inter rivers of the basin under study, one attributes the same classification applied to the surfaces with morphometric index 11. Thus, the morphometric categories were classified according to the instability potential, which is known to be higher in the steepest surfaces, while in the softer ones, tends to be lower (Table 2):

TABle 2. Classes of Fragility fOR LANDFORMS CATEgory. AdAPTED From ROSS (1994) IN SILVA (2010)

Tabla 2. Clases de fragilidad por categoría de paisajes. Adaptada de ROSS (1994) en SILVA (2010)

\begin{tabular}{|c|c|c|}
\hline Fragility & Morphometric categories (Modeled) & Code \\
\hline Very weak & 11 & 1 \\
\hline Weak & $21,22,12$ & 2 \\
\hline Medium & $31,32,33,13,23$ & 3 \\
\hline Strong & $41,42,43,44,14,24,34$ & 4 \\
\hline Very strong & $51,52,53,54,55,15,25,35,45$ & 5 \\
\hline
\end{tabular}

The units corresponding to the types of rocks were classified according to CREPANI et al. (2001), which attributed relative and empiric positions to the lithologys more commonly found, within the vulnerability scale to denudation (weather instability + erosion) referring to the level of cohesion of eruptive, metamorphic and sedimentary rocks.

The authors have defined a scale which ranges from 1 to 3 according to TRICART (1977) Echodynamic Units (unstable, intergrades and strongly unstable), respectively. However, according to the definitions attributed by the authors, the scale used was adapted for this work according to levels of fragility from Very Weak to Very Strong, concerning rocks occurring in the areas of (Table 3). One stands out that the classification made in this work is not directly proportional to the one by CREPANI et al. (2001), once we have searched to assess qualitatively the levels of rock vulnerability.

Table 3 Fragility Classes for rock CATEgories. (SILVA 2010).

Tabla 3. Clases de fragilidad por categorías de roca. (SILVA 2010).

\begin{tabular}{|c|c|c|}
\hline Fragility & Rock class & Code \\
\hline Very weak & Basalts - São Bento group & 1 \\
\hline Weak & Gneiss - Suíte Jurubatuba & 2 \\
\hline Medium & Schist - Araxá group & 3 \\
\hline Strong & Sandstone - Bauru group & 4 \\
\hline Very strong & Cenozoic deposits & 5 \\
\hline
\end{tabular}


For Soil classification the methodology follows the proposition of ROSS (1994), in which it used criteria about the texture, structure, plasticity characteristics, level of cohesion of particles and depth/thickness of profiles. These characteristics are intimately related to landforms, rocks, climate, pedogenesis, among other important factors for determining the chemical and mechanical attributes of the soil. This way, for the variable of soil, the fragility classes were expressed in the Table 4.

Relating to the classes of Land Use and Vegetation Cover, the methodology determines a hierarchy from its protection levels to the soil, following a decreasing order of this protection capacity. Thus, a forest area (natural) has a higher protection to the soil than the bare Cerrado. In the same way, these two previous classes have a higher protection capacity than a pasture or agriculture area, which, at its time, reveal to be more favorable than the exposed soils. The level of degradation or preservation of mapped classes is not evaluated at this scale of treatment, so the protection level is considered the same for the whole mapped area. The classification of Land Use and Vegetation Coverage classes can be checked in the Table 5.

Table 4 - Fragility Classes for Soll categories. (SILVA 2010).

Tabla 4. Clases de fragilidad por categorías de suelo. (SILVA 2010).

\begin{tabular}{|c|c|c|c|}
\hline \multirow{2}{*}{ Fragility } & \multicolumn{2}{|c|}{ Soil categories } & Code \\
\cline { 2 - 4 } & Symbol & Soil Association & 1 \\
\hline Very low & LVaf & RED LATOSOL Aluminium iron- & 1 \\
\hline Very low & LVd1 & RED LATOSOL Dystrophic epialic- & 1 \\
\hline Very low & LVd2 & RED LATOSOL Dystrophic or Dystrophic epialic & 2 \\
\hline Low & LVd3 & $\begin{array}{c}\text { RED LATOSOL Dystrophic or Aluminium iron and CAMBISOL HÁ- } \\
\text { PLIC Eutrophic }\end{array}$ & 3 \\
\hline Medium & LVe & $\begin{array}{c}\text { RED LATOSOL Eutrophic, CAMBISOL HÁPLIC Eutrophic and NEO- } \\
\text { SOL LITOLIC Eutrophic }\end{array}$ & 3 \\
\hline Medium & LVAa & RED-YELLOW LATOSOL Aluminium or Dystrophic epialic & 4 \\
\hline Strong & CXbe1 & $\begin{array}{c}\text { HAPLIC CAMBISOIL Eutrophic, NEOSOL LITOLIC Eutrophic and } \\
\text { RED NITOSOL Eutrophic }\end{array}$ & 4 \\
\hline Strong & CXbe2 & HAPLIC CAMBISOL Eutrophic and LITOLIC NEOSOL Eutrophic- & 4 \\
\hline $\begin{array}{c}\text { Very } \\
\text { strong }\end{array}$ & PVAe & $\begin{array}{c}\text { RED -YELLOW ARGISOL Eutrophic and HAPLIC CAMBISOL Eu- } \\
\text { trophic- }\end{array}$ & 5 \\
\hline
\end{tabular}

Having in mind all these categories classified, one has pondered the attributes according to their level of importance about the generation of erosive processes. It has to be highlighted that the addition of the pondering of all elements must be equal to 100\% (PEDROSA et al. 2012). 
Table 5. Fragility classes for the category Land Use and Vegetable Coverage. (SILVA 2010)

Tabla 5. Clases de fragilidad por categoría de uso del suelo y cobertura Vegetal. (SILVA 2010)

\begin{tabular}{|c|c|c|}
\hline Protection levels & Use of land and vegetation coverage categories & Code \\
\hline Very high & Forests/Cerrado/Forestation & 1 \\
\hline High & Pasture & 2 \\
\hline Medium & Urban use & 3 \\
\hline Low & Permanent culture & 4 \\
\hline Very low & Temporary culture & 5 \\
\hline
\end{tabular}

According to GUERRA (2007) the factors which control the erosive processes are the ones which determine their variations such as rain erosion, soil properties, vegetation cover and slope characteristics. The interaction of these factors is responsible for the higher or lower erosion index occurring in several areas. Consequently, anthropic attitude may alter these factors, contributing to its acceleration or retarding.
Therefore, the attribution of pondered values to the several variables used for the assessment of environmental fragility of the area under study must be taken as being relative and empiric, according to the acquired knowledge about the erosive processes in tropical regions. Thus, Table 6 synthetizes pondering attributed to the different elements constituting the object of environmental analysis of the basin under study:

Table 6 - Weight Values for enVironmental elements. (SILVA 2010)

Tabla 6. VAlores de PONDERACión de los Elementos ambientales. (SILVA 2010)

\begin{tabular}{|c|c|c|c|}
\hline $\begin{array}{c}\text { Pondered values for obtaining the } \\
\text { potential fragility }\end{array}$ & \multicolumn{2}{|c|}{$\begin{array}{c}\text { Pondered values for obtaining the emerging fragility } \\
\begin{array}{c}\text { Environmental } \\
\text { attributes }\end{array}\end{array}$} & $\begin{array}{c}\text { Pondering } \\
(\%)\end{array}$ \\
\hline Landform & 45 \\
\hline Soils & 35 & Variables & $\begin{array}{c}\text { Pondering } \\
(\%)\end{array}$ \\
\hline Rock type & 20 & Potential Fragility Map & 50 \\
\hline
\end{tabular}

\section{RESULTS}

\section{Potential Fragility of Environment}

Analysis of Environmental Fragility through weighed overlay applied to the Medium Lower Araguari River Basin, according to methodological propositions by ROSS (1994), resulted in two products which have permitted spatialization of areas more vulnerable to the erosion processes.
The first of them corresponds to the cross of geomorphological, geological and soil information, which resulted in the fragility potential map (Fig. 4). Such cartographic product, points to the levels of natural fragility of the basin, which must be taken into consideration in the processes of anthropic occupation, considering the environmental balance of the geographic regions to be kept, which is not always held. 
In this context, the methodological procedures adopted permitted to get to a nonparametric classification of the area under study. Four classes of potential fragility were identified (Table 7), which are as follows: Very low, Low, Medium and High. The Very High class was not found, which is related with the variation of landforms Standards, which, in the Ross classification, did not receive the value corresponding to the highest level of fragility.
The figure 8 points that the more fragile areas facing the erosive processes occur in all extension of the valley bed, associated to schist and gneiss of Pre-Cambrian and to the high dissection landforms. In these tracks, the soils also have fragility indexes ranging from High to Very High.

Table 7. Area occupied by each class of Potential Fragility. (Silva 2010)

Tabla 7. Área ocupada por cada clase de Fragilidad Potencial. (SILVA 2010)

\begin{tabular}{|c|c|}
\hline \multicolumn{2}{|c|}{ Occupied area by Potential Fragility classes } \\
\hline Class & $(\%)$ \\
\hline Very low & 5,13 \\
\hline Low & 39,30 \\
\hline Medium & 29,20 \\
\hline High & 26,37 \\
\hline
\end{tabular}

In general, one can say that the basin presents a potential fragility profile which obeys the topographic energy of the land, which increases in the proportion of the falling in the altimeter quotes. However, it is worth highlighting that, even top flat areas still present variations from Low to Medium fragilities, outstanding, specially, by the presence of deposits of Cenozoic age.

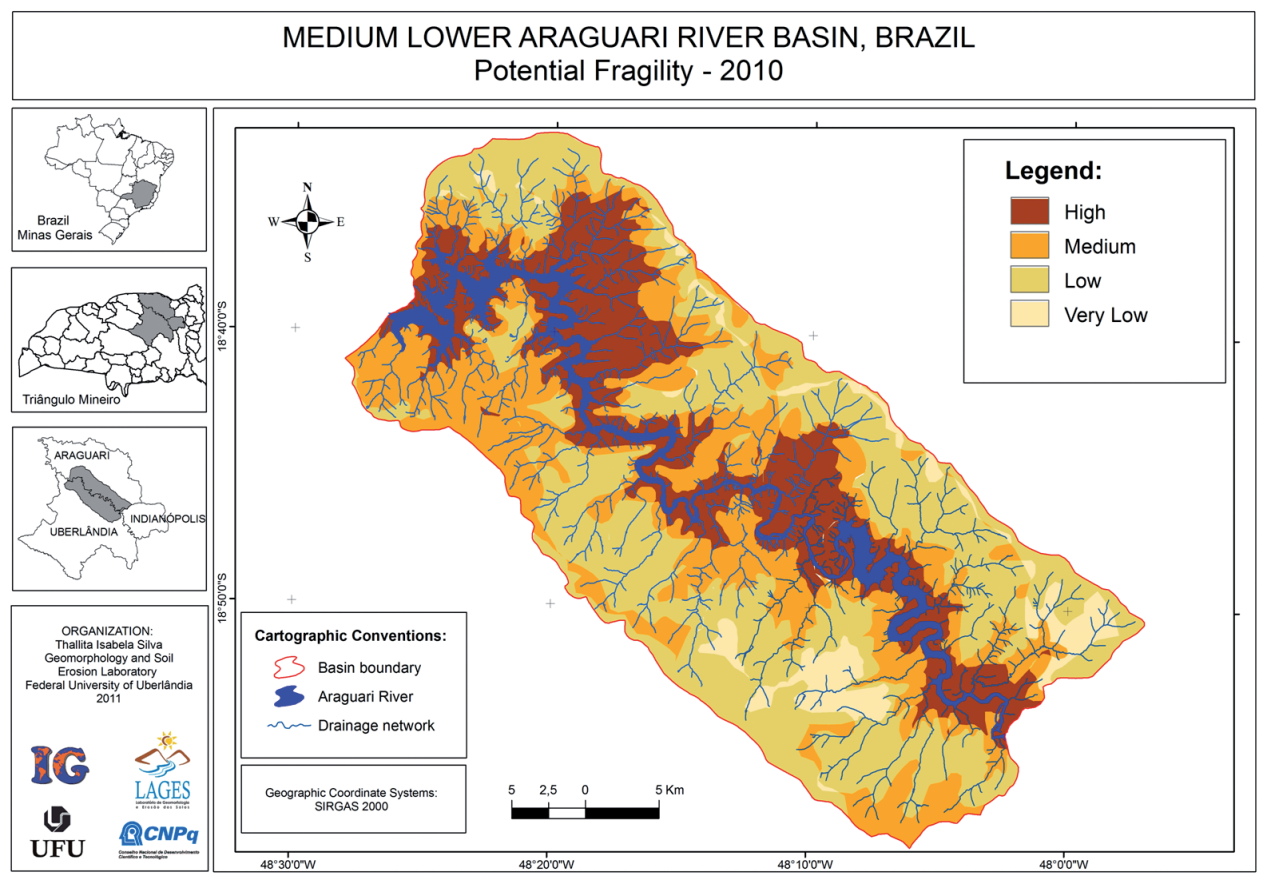

Fig. 4. Map of Potential Fragility of Medium Lower Araguari River Basin. (SILVA 2010) Fig. 4. Mapa de Fragilidad Potencial de la cuenca media-baja del río Araguari. (SILVA 2010) 


\section{Emerging Fragility of Environment}

The second resulting product corresponds to the Emerging Fragility Map, in which spatialization of human activities on the surface is considered. It demonstrates the current environmental situation facing anthropic interventions, as well as the susceptibility level to the erosion from Very Low to Very High.
Spatialization of classes of fragility may be verified in the Table 8, from what can be seen that Medium Fragility is predominant, corresponding to $47,55 \%$ of the occupied area, which corresponds to more than 550 $\mathrm{km}^{2}$ of extension. This class refers to the valley depths and to the occupied areas by urban use.

Table 8. Area occupied by Classes of Emerging Fragility (SILVA 2010)

Tabla 8. Área ocupada por clases de Fragilidad Emergente (SILVA 2010)

\begin{tabular}{|c|c|}
\hline \multicolumn{2}{|c|}{ Occupied Area by classes of Emerging fragility } \\
\hline Class & $(\%)$ \\
\hline Very low & 1,08 \\
\hline Low & 39,28 \\
\hline Medium & 47,55 \\
\hline High & 11,89 \\
\hline Very high & 0,20 \\
\hline
\end{tabular}

Figure 5 clarifies the spatialization of emerging fragility classes and makes diagnosis of environmental fragility of Medium Lower Araguari River Basin possible. This result is a potential tool for contributing to the elaboration of deeper environmental studies which aim to the application of a more efficient environmental planning.

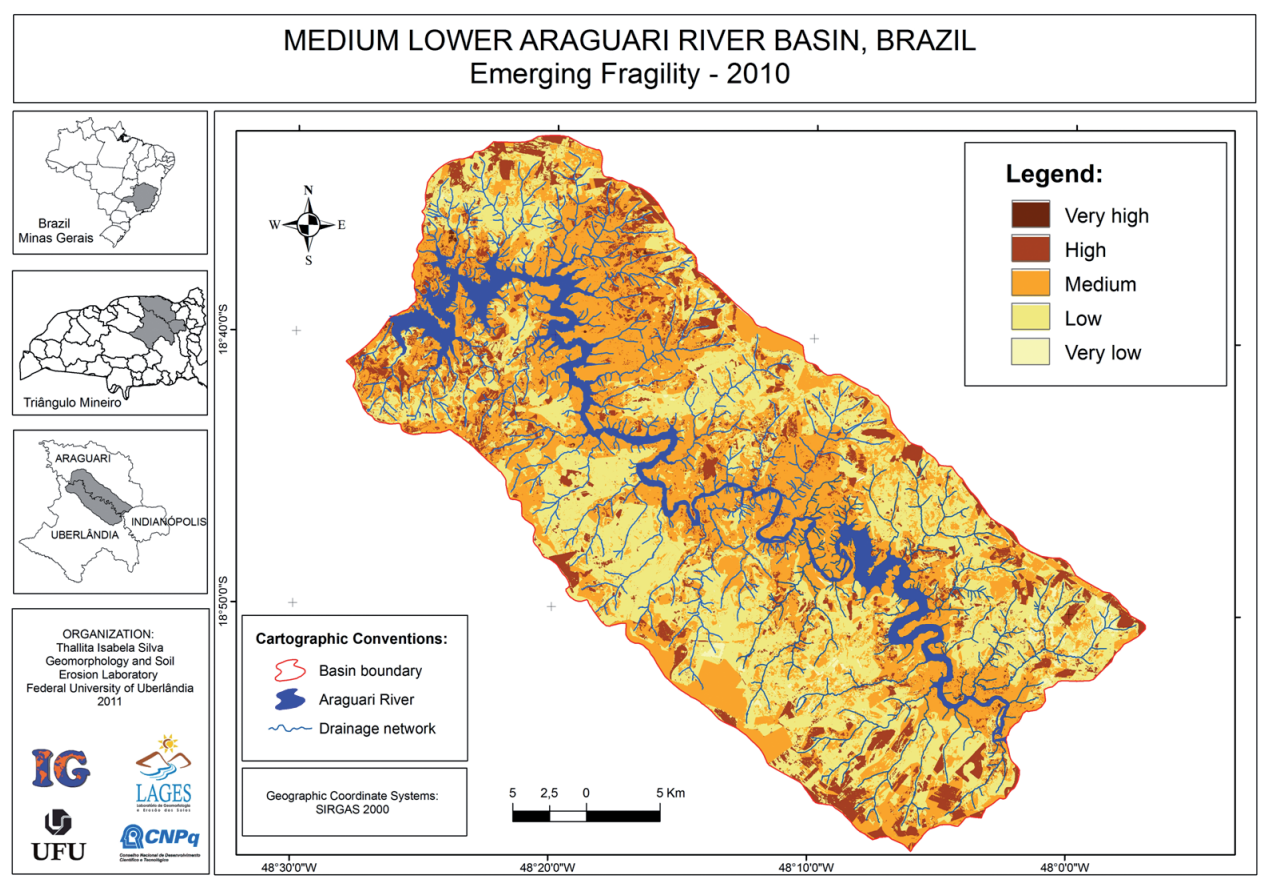

Fig. 5. Map of Emerging Fragility of landscape (SILVA 2010).

Fig. 5. Mapa de Fragilidad Emergente del paisaje (SILVA 2010). 


\section{DISCUSSION}

The results presented demonstrate applicability of geotechnologies to the landscape modeling, which may serve as a basis not only related to environmental fragility analysis, but also to different aspects one may wish to focus. However, it is necessary to point that the existence of several methodologies supported by various tools within the SIG, as it can be seen in SOUZA (2009); CRUZ et al. (2010), and also in other authors, such as CÂMARA \& MEDEIROS (1998) and CREPANI et al. (2001). These two latter reinforce the theorization of applications in remote sensing and geoprocessing, turned to, specially, the areas of Physical Geography and Environmental Sciences.

Referring to the work of CRUZ et al. (2010), these authors made, based in ROSS (1994), the qualitative analysis for the potential fragility definition of different factors - land uses, level of steepness and type of soil - of a hydrographic basin. Its methodological procedure based on the attribution of values taking into consideration that all factors would have the same influence over the fragility of the area studied. There was the cross of different attributes from an addition, that is, the regions add their weights related to degradation, land use, steepness and type of soils, generating a synthesis product which determines the environmental quality of the studied area. Studies performed in the same type of biome by CRUZ et al. (2010) found that more than $60 \%$ of the study area are included in the classes of medium, strong and very strong fragility, and admit that the main parameter influencing these results is the type of land use. The research done by SOUZA (2009) in a landscape with very steep slopes but with natural vegetation cover shows that $40 \%$ of the studied area is located in medium, strong and very strong fragility. In other direction PINESE JUNIOR \& RODRIGUES (2012) found results similar to CRUZ et al. (2010) with more than $65 \%$ of studied area in classes higher than medium fragility, with land uses classes of pasture and agriculture predominantly. Apparently in all these studies, using the same methodology, the land use parameter is the most important to determine changes in the percentage of areas with medium or more fragility of the landscape.

The methodology of such authors pointed to the advantages in the sense of reproducing an approach to the reality, however, from the operational point of view, it demands more amount of time, once the layers used in the cross of data consist of format shape, not permitting conventional spatial analysis, held through archives in the raster format. As a counterpart, the methodology used in this work -modeling through weighed overlay- resulted in a reduction of tasks fulfilling time in SIG

It is suitable to highlight that the modeling based in weights overlay demands good knowledge of this technique, as well as, reflecting the judgement of specialists concerning the analysis performed, enable that they be easily adjusted during the assessment procedure. However, it is a technique of linear nature, which has as limitation due to the fact that it considers the weighs attributed as constants along the information plan, which, at times, make some parameters to have lower importance in some regions, interfering with the final result of the analysis (MEIRELLES et al. 2007).

In this sense, it is important to remember that a model searches to represent an approach to the reality, and, the advance in the development of new techniques is really relevant for the improvement of environmental researches and as a contribution to the elaboration of territorial plans at public service. This work has searched, therefore, the representation of environmental fragility of the Medium Lower Araguari River Basin, as well as the demonstration of the application of the 
technique of weigh overlap, a practical tool, however, that must be used with caution due to its limitations.

\section{CONCLUSION}

The proposed study tries to understand the fragility of a landscape located in the Cerrado Biome in the central uplands of Brazil, with focus in the Lower Medium Araguari River Watershed. The fragility analysis is based in the echodynamic approach proposed by TRICART (1977) and in the operational procedures organized by ROSS (1994). In the way, the study tries to understand what are the importance of landscape parameters to determine Potential Fragility, that is due to natural properties of the landscape, and the Emerging Fragility, which are associated to the changes in the land use of a region.

In this study the test of the methodology shows that the combination of steepness of slopes and type of land uses are the main parameters that influence the fragility of landscape.

For this study the combination of occupied area by classes of medium and high Potential Fragility summed $55,57 \%$ and increase to $59,64 \%$ of the total area when the Emerging Fragility map is analyzed, showing that the type of land uses which are distributed over the landforms are not in accordance with the capacity of support of the landscape.

Potential fragility analysis contributed to the understanding of natural vulnerability of the basin under study, stronger in the valley depths and the areas of more dissected modeled. The cross of these pieces of information with the ones of land use and vegetable coverage pointed to the emerging fragility, which gives the influence of human occupation of the environment. It was from this synthesis chart that one has reached the diagnosis of the damage of the basin resources, bearing in mind its application to the development of plans and actions which mitigate or correct the impacts on the inappropriate uses, value and conserve the environment which is still preserved.

\section{ACKNOWLEDGEMENT}

To the Science and Technology National Council - CNPq for the support to this work through the Project 473701/2010-3. This research is also included in the CAPES PROCAD 067/2007.

\section{REFERENCES}

CÂMARA, G. \& J. S. MEDEIROS, 1998. Geoprocessamento para Projetos Ambientais. Instituto Nacional de Pesquisas Espaciais. São José dos Campos, http://www.dpi.inpe.br/gilberto/tutoriais/ gis_ambiente/

CREPANI, E., J. S. MEDEIROS, P. HERNANDEZ FILHO, T. G. FLORENZANO, V. DUARTE \& C. C. F. BARBOSA, 2001. Sensoriamento Remoto e Geoprocessamento Aplicados ao Zoneamento Ecológico-Econômico e ao Ordenamento Territorial. Instituto Nacional de Pesquisas Espaciais. São José dos Campos. ttp://www.dsr.inpe.br/dsr/simeao/ Publicacoes/SERGISZEE3.pdf.

CRUZ, L. M., J. F. PINESE JUNIOR, \& S. C. RODRIGUES, 2010. Abordagem Cartográfica da Fragilidade Ambiental na Bacia Hidrográfica do Glória-MG. Revista Brasileira de Cartografia. 62 (3): 505-516. 
GUERRA, A. J. T., 2007. Processos Erosivos nas Encostas. In: Guerra, A. J.T. \& S. B. Cunha, (Eds.). Geomorfologia: uma atualização de bases e conceitos. Bertrand Brasil, Rio de Janeiro, pp. 149-209.

MEIRELLES, M. S. P., F. R. MOREIRA, \& G. CÂMARA, 2007. Técnicas de Inferência Espacial. In: Meirelles, M. S. P., G. Câmara \& C. M. Almeida, Geomática: Modelos e Aplicações Ambientais. Empresa Brasileira de Pesquisa Agropecuária. Informação Tecnológica, Brasília, pp.106189.

PEDROSA, A. S., E. A. V. ROCHA, \& S. C. RODRIGUES, 2012. Proposta de Modelagem da Suscetibilidade a Erosão Laminar. Um Estudo de Caso na Bacia do Ribeirão Vai Vem (Go). Brasil. Revista Geonorte, 2: 1707-1720.

RODRIGUES, S. C., 1998. Análise Empírico-Experimental da Fragilidade Relevo-Solo no Cristalino do Planalto Paulistano: sub bacia do reservatório Billings. Thesis (Doctorate thesis in Physical Geography) - Departamento de Geografia, Universidade de São Paulo, São Paulo, 265pp.

ROSA, R., 2007. Introdução ao Sensoriamento Remoto. Edufu, Uberlândia: 228pp.
ROSS, J. L. S., 1992. O registro cartográfico dos fatos geomorfológicos e a questão da taxonomia do relevo. Revista do Departamento de Geografia, 6:17-30.

ROSS, J. L. S., 1994. Análise empírica da fragilidade dos ambientes naturais e antropizados. Revista do Departamento de Geografia, 8: 63-74.

SILVA, T. I., 2010. Diagnóstico e Análise da Fragilidade Ambiental da Bacia do Médiobaixo Curso do Rio Araguari, Minas Gerais. Term paper for Graduation in Geography - Instituto de Geografia, Universidade Federal de Uberlândia, Uberlândia, 88pp.

SOUZA, N. C., 2009. Mapeamento da fragilidade ambiental no Trecho de Vazão Reduzida do Rio Araguari (MG) utilizando técnicas de geoprocessamento. Term paper for Graduation in Geography - Instituto de Geografia, Universidade Federal de Uberlândia, Uberlândia, 52pp.

TRICART, J., 1977. Ecodinâmica. Fundaçao Instituto Brasileiro de Geografia e Estatistica, Rio de Janeiro, 97 pp. 


\section{Imagen de Investigaciones GEOGRAFICAS}

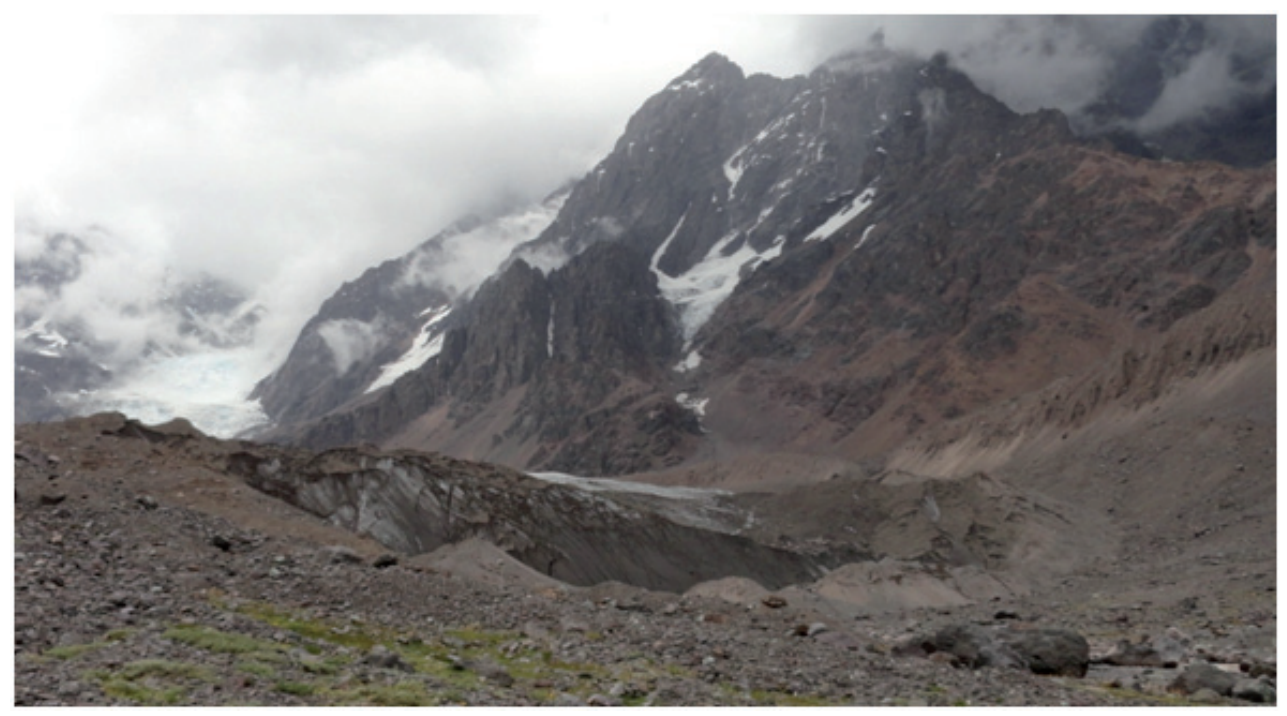

Fotografía de Diciembre 2012 que muestra el estado actual del frente del Glaciar Juncal Norte en las nacientes de río homónimo, Valle del Río Aconcagua. Se observa un arco morrénico de recesión, el cual se encuentra a unos 30 metros del actual frente de hielo. Este frente presenta un color gris oscuro (hielo negro) producto de la gran cantidad de material detrítico intraglacial resultado del balance de masa negativo imperante, lo que provoca un aumento proporcional de la morrena interna respecto de la masa de hielo. En la ladera se visualizan restos del cordón morrénico lateral antiguo, cerca de $\mathbf{5 0}$ metros por sobre la lengua del glaciar, lo que atestigua su fuerte adelgazamiento (F. Ferrando Acuña).

CInvestig. Geogr, Chile, todos los derechos reservados. 